\title{
Changing Climate and the Effect of Gully Erosion on Akpo Community Farmers in Anambra State, Nigeria
}

\author{
Angela A* and Ezeomedo IC \\ Department of Environmental Management. Faculty of Environmental Sciences, \\ Chukwuemeka Odumegwu Ojukwu University, Nigeria
}

*Corresponding author: Angela Akanwa, Department of Environmental Management, Faculty of Environmental Sciences, Chukwuemeka Odumegwu Ojukwu University, (COOU) P.M.B. 02 Uli Campus, Anambra State, Nigeria, Email: angela.akanwa1@gmail.com

\section{Research article \\ Volume 2 Issue 6}

Received Date: October 27, 2018

Published Date: November 09, 2018

DOI: $10.23880 /$ jenr-16000147

\section{Abstract}

Climate variability has increased rainfall intensity resulting in floods and storms which have aggravated environmental and land degradation problems globally. Land degradation problems such as gully erosion happen to be a big threat to agricultural development and rural livelihood in developing countries. Gully erosion affects lands, soils, and vegetation, water and landscape resources in areas where it is prevalent. This study therefore, investigated changing climate and the effect of gully erosion on Akpo community farmers in Anambra State, Nigeria. The field survey and Remote Sensing and GIS techniques were employed in this study. The survey approach involved questionnaire distribution, observation, interviews and photography. 95 questionnaires were randomly sampled to Akpo farmers. Remote Sensing/ GIS techniques were used for detecting and mapping gully erosion prone areas. The gully characterization was carried out using Digital Elevation Model (DEM) as a prerequisite for assessing the relationship between field topography and gully occurrence. The geometry of the eroded channels especially their width (W) and depth (D) was characterized through its cross section width and maximum depth.The hypotheses were was tested using chi-square $\left(\mathrm{x}^{2}\right)$. The results showed that a large proportion of $(94 \%)$ farmers were below tertiary education and the land could be their only means of livelihood. Also, majority of the farmers (63.2\%) agreed that rainfall has exacerbated gully activities and is majorly responsible for the large degradation of farm lands. Also, $40 \%$ indicated that gully erosion has affected their crop production levels. Findings also indicated that gully erosion in Akpo community is dendritic and has a network of branches. Gully erosion characterization indicated a V-shape representing that the surface soils are more erodible than the subsurface soils due to surface run-off producing concentrated overland flows that cut channels. Further, the gully length (563m), maximum elevation $(226 \mathrm{~m})$, and elevation gain $(0.9 \mathrm{~m})$ and maximum slope $(2.2 \%)$ which happens to be responsible for the large distribution of the gullies on the spots along farmlands aiding the generation of sufficient volume of run-off. Farmers revealed that gully erosion has the most significant effect on farmlands, poor growth/harvest of crops (especially 
economic trees like Avocado, Pear, Kola nut, Breadfruit and Berry), and destruction of arable lands, shortage of land for other uses, loss of biodiversity and reduction of farmers' income. Adaptive measures like afforestation and agroforestry systems, developing flood channels for storm water, creation of farmers group to enable tackle the erosion problems and policy enforcement on human actions that trigger climate change are recommended.

Keywords: Changing Climate; Rainfall Pattern; Gully Erosion; Livelihood; Run-Off and Farmers

\section{Introduction}

According to the U.S. Environmental Protection Agency (2017) the term climate change is often used interchangeably with the term global warming, but according to the National Academy of Sciences, "the phrase 'climate change' is growing in preferred use to 'global warming' because it helps convey that there are other changes in addition to rising temperatures [1]." There has been an increase Earth's average surface temperature from 1.2 to $1.4^{\mathrm{o}} \mathrm{F}$ since 1900 and the past two decades has recorded the hottest temperatures globally [2].

Rising temperatures are expected to be an increasing trend since global warming is a consequence of human activities (burning fossil fuels, deforestation, reforestation, urbanization, desertification, etc) that influences rainfall patterns, heat intensity and frequency of storms, rising sea levels and much more [3].

Developing countries like Nigeria have also experienced dramatic changes in weather over the years especially towards intense rainfall and incessant flooding problems. Nigeria Meteorological Agency (NIMET, 2018) confirmed that there have been changes in the Nigeria's climate as proven observations from 1941 to 2000 showed evidence of long-term temperature increase in most parts of the country [4]. The rising temperature trend showed an increase in temperature when averaged over the country from about $26.2^{\circ} \mathrm{C}$ in 1951 to about $27.6^{\circ} \mathrm{C}$ over the years.

In addition, climate change indicated by weather patterns of intense rainfalls coupled with soils type are important factors that can generate high runoff volumes that accelerate gully erosion [5,6]. Notably, there is a relationship between soil erosion and climate change as relevant aids that can accelerate gully erosion problems $[7,8]$. Several studies have been carried out to authenticate that intense rainfall coupled with sandy/silt soils can initiate soil erosion problems [9-16].
Gully erosion can be referred to as a global phenomenon that provokes geographical instability $[17,18]$. It remains one of the most challenging environmental problems in both developing and developed countries [19]. The United States Global Change Research Information Office (2001) stated that approximately 90 percent of cropland in the United States is currently losing soil above the sustainable rate; the erosion rates in Asia, Africa and South America are estimated to be as high as those in the United States [20]. In Nigeria, gully erosion problems has become starkly apparent in major urban and rural areas especially AguluNanka in Anambra State where 250 tons per hectare of arable lands have been lost to gully erosion [21,22].

Gully erosion is a major problem in the world that affects agricultural production, landscapes, infrastructures, aesthetics, land value, settlements, arable farmlands and vegetation, soil fertility/productivity and animal and human lives [23-28].

The concept of sustainable development would be an appropriate strategy for agrarian communities to best conserve their agricultural lands which serves as their source of livelihood. According to World Commission on Environment and Development (1987) defines sustainable development as "development that meets the needs of the present generation without compromising the ability of future generations to meet their own needs" [29]. The core component of this definition is the conservation and development of all resources especially land which sustains all life on earth. This makes up the main thrust of this study since climate change can influence rainfall intensity and thus, arable farmlands, farming activities, levels of crop yield and livelihood can be grossly threatened.

\section{Statement of Problem}

Most Nigerian rural areas are agrarian and totally depend on adequate rainfall for agricultural production. Consequently, there has been incessant rainfall in 
Anambra State showing increased wetter-than-normal conditions. The extent and intensity of the floods in Anambra State is very alarming putting agricultural activities at high risk of being threatened and farmers denied of their major means of survival. This will affect their social lives as well, since farming is not just a means of survival, but also a lifestyle for most rural settlements in Nigeria [30]. Further, the overwhelming problem of increased rainfall intensity, floods and storms in Anambra State have been proven to be as a result of climate change [31]. Apparently, intense rains can facilitate gully erosion and thereby, affect agricultural production. This can frustrate farmers and increase food insecurity in rain-fed agrarian areas. Erosion losses can be significantly correlated with rainfall intensity, runoff and percent ground cover which can account for as much as $86 \%$ of variability in soil erosion $[32,33,36]$.

Noticeably, climatic fluctuation is pulling Nigeria's agricultural system under serious threat and changing livelihood patterns [34]. Moreover, Anambra State experiences eight months of rainy season and four months of dry season which is typical of the tropics and thus, with its weak lithology and the eroding energy of runoff maximum, the susceptibility of this area to gully erosion is predominantly high $[35,36]$. Despite the threat posed by the gullies on the farm lands in the area, the farming approach employed by the farmers also constitute a setback that could exacerbate the situation. The use of continuous/intense farming system which leads to bush burning reduces vegetation cover and exposes the bare surface of the soil to runoff. The felling down of trees in the gullied areas in large quantities are used for both personal and commercial uses and the sloping terrain makes it easy for the changing climate associated with increased rainfall to easily detach soil particles.

Clearly, gully erosion is the worst stage of all types of erosion and it affects several soil functions and hence soil quality $[27,28]$. It damages farmlands, arable lands, causes low crop yield, soil moisture decrease, food insecurity, loss of economic trees, lives, dislocation of families from their ancestral homes and loss of valuable properties [37,17]. Hence, the aim of this study is to investigate the changing climate and the effects of gully erosion on Akpo community farmers in Anambra State, Nigeria with the following objectives;

1. To identify the level of awareness and extent of gully erosion on Akpo community;

2. To examine the level of effect of gully erosion on agricultural production;
3. To determine socio-economic effect of gully erosion on the residents and farmers at Akpo community;

\section{Study Area}

Akpo is located in Aguata local government area, Anambra State (Figure 1). It is made up of six (6) villages namely: Agbelu, Uhuala,Umueze, Ogbo, Amaife and Udo which make up Akpo Town (Figure 2). It shares boundaries with Orumba North in the North, in the South with Imo State, with Orumba South in the West with Nnewi South in the East. The geographical location of Akpo falls within these co-ordinates: Latitude $05^{\circ} 56^{\prime} 35^{\prime \prime}$ $\mathrm{N}$ to $06^{\circ} 59^{\prime} 10^{\prime \prime} \mathrm{N}$ and Longitude $07^{\circ} 05^{\prime} 40^{\prime \prime} \mathrm{E}$ to $07^{\circ} 06^{\prime}$ $40^{\prime \prime}$ E. The population of Akpo was 21,440 in 2006 (NPC,2006) which has been projected to 31,288 in 2018 based on the approved 3.2\% annual population growth rate by the National Population Commission. Akpo is in the tropical rainforest zone of Nigeria which has been replaced with derived savannah by human activities such as deforestation and intensive agriculture. The main occupation of Akpo people is farming they depend mainly on agriculture and business/trading for their daily livelihood. Topographically, the area is characterized by rolling undulating terrain. Most of the lowlands are rivers or streams that trigger major morphological expressions of massive sheet, rills, channel and gully erosion. Akpo experiences two distinct seasons - a wet season of abundant rainfall.

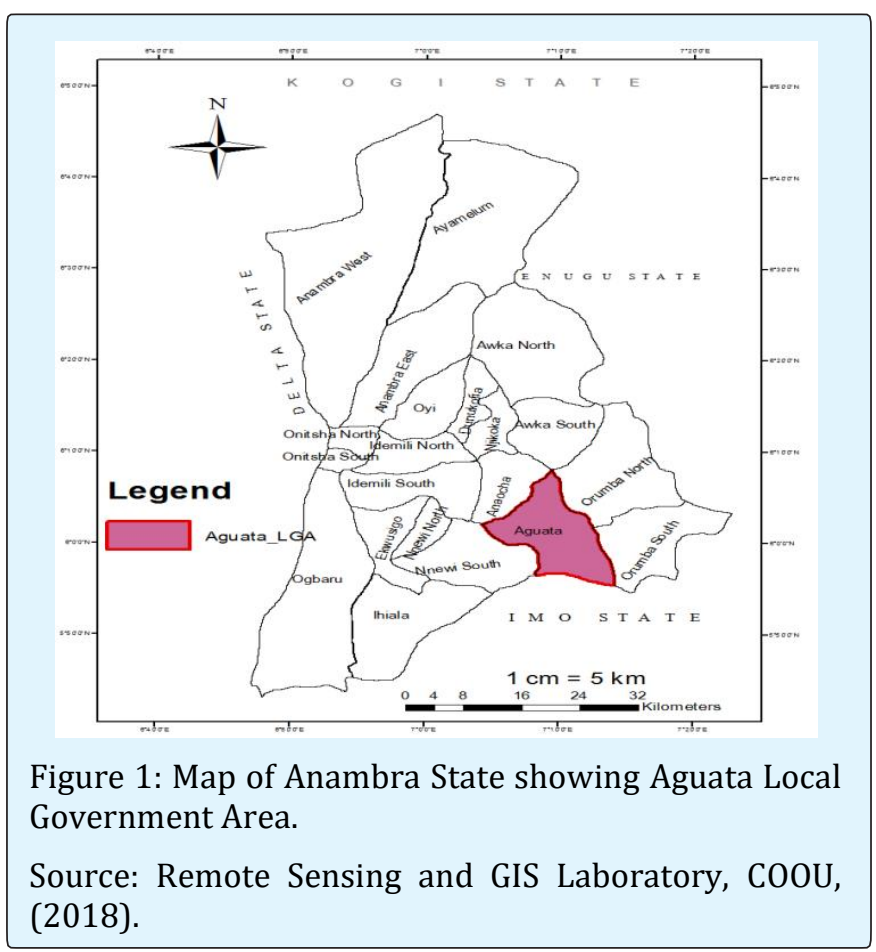




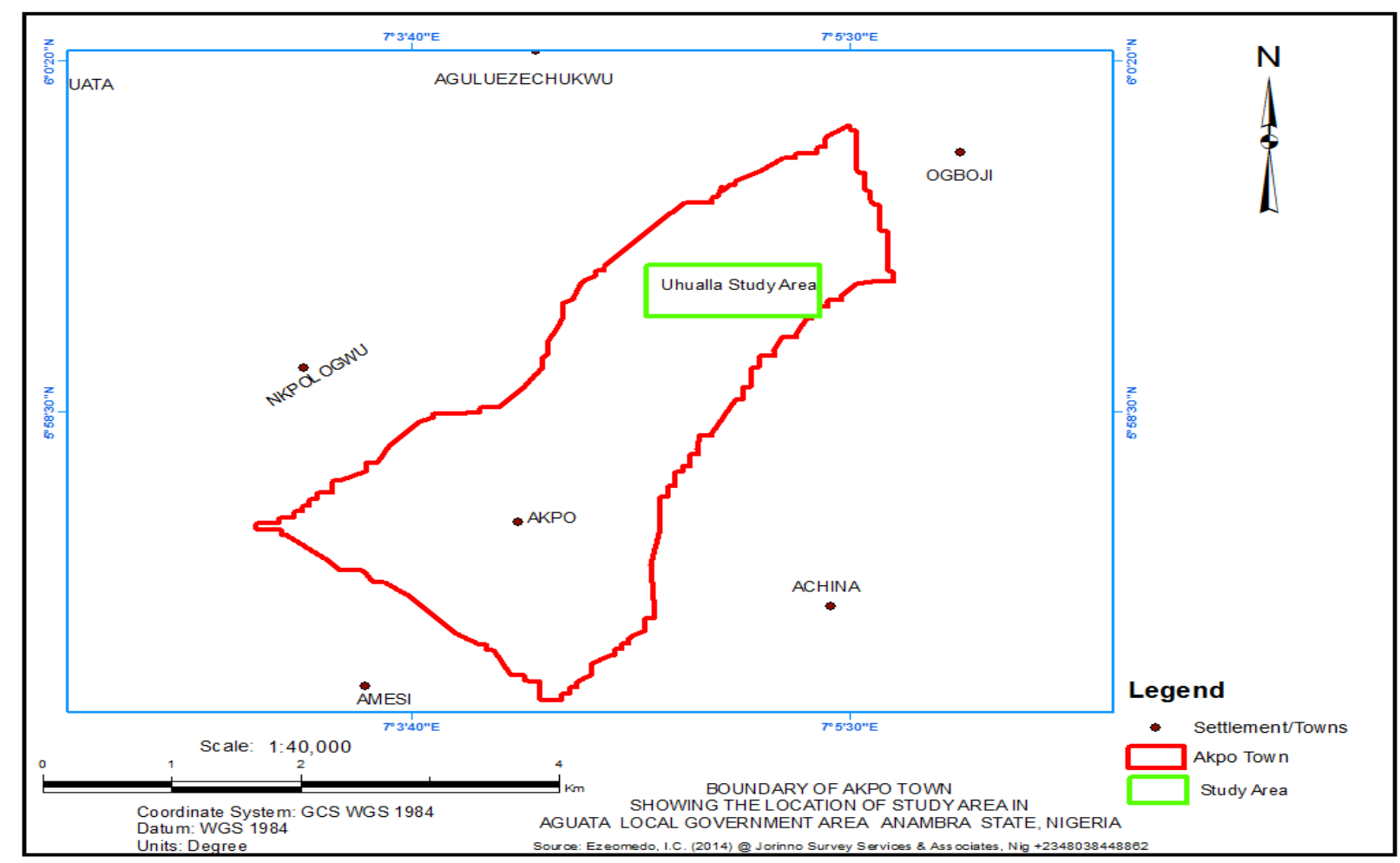

Figure 2: Boundary of Akpo Town showing the study area at Uhuala-Village.

Source: Ezeomedo, I.C. (2018).

\section{Materials and Methods}

The study investigated the changing climate and the effects of gully erosion on Akpo community farmers in Anambra State, Nigeria. The study employed Field survey and Remote sensing/GIS methods. The survey approach involved questionnaire distribution, observation, interviews and photography. 95 questionnaires were randomly sampled to Akpo farmers while the Remote Sensing/ GIS techniques were used for detecting and mapping erosion prone areas. The gully characterization was carried out using Digital Elevation Model (DEM) as a prerequisite for assessing the relationship between field topography and gully occurrence. The geometry of the eroded channels especially their width (W) and depth (D) was characterized through its cross section width and maximum depth and the stated hypotheses were tested using chi-square $\left(\mathrm{x}^{2}\right)[38]$.

\section{Results and Discussion}

\section{The level of Awareness and Extent of Gully Erosion on Uhuala Village}

The sex of the respondents indicated that $63.2 \%$ of the respondents were male and $36.8 \%$ of the respondents were female. This showed that there were more male farmers than female farmers. During the interview session with the farmers, the researcher was able to confirm that farming in Uhuala is mainly at the subsistence level and its nature requires hard labour and rigorous hours of planting, weeding, storage etc which the farmers (Men) are primarily involved. The women usually farm as an alternative especially during the planting season to assist their families at the early planting seasons and during harvest while combining it with home keeping and other activities. 


\section{Journal of Ecology \& Natural Resources}

The study also observed that the age structure of the respondents were $15.8 \%$ for those between $21-30$ years, $26.3 \%$ for those between $31-40$ years, $36.8 \%$ for those between $41-50$ years and $21.1 \%$ for those aged 51 and above. The age structure showed that the majority of the farmers were adults (41-50 years). Noticeably, farming is labour -intensive in Uruala village requiring maturity and skilfulness in the art of crop production.

The study observed that $10.5 \%$ of the respondents had no formal education, $31.6 \%$ had primary education, $52.6 \%$ had secondary education and $5.3 \%$ had tertiary education. This is an indication that majority of the farmers could read and write. Owing to the level of education, the farmers were able to indicate that there were changes in the rainfall pattern accompanied by increased intensity of floods affecting the terrain. Although they attributed that "climate change" is only a sign that the "rain god" was angry at them showing in the socio-economic losses and extreme weather and climatic events like floods and storms that have greatly affected the performance of their crop produce. It can be deduced that although the farmers could not clearly identify climate change as a scientific phenomenon, nor project the greenhouse effect, neither predict all the elements that determine the state and dynamics of the earth climate. Unarguably, majority of the farmers could relate to the fact that there is a change in rainfall intensity which has increased the spread of gully erosion across their lands, changing their growing seasons, poor performance of their harvest; most of all food security and livelihoods have become threatened. These findings were confirmed by a similar study carried out by Ayinde et al. and Abdulfatai, et al. that increased rainfalls initiate gully erosion trends that affect agricultural production $[28,34]$.
Further, figure 3 showed the main gully site in the satellite image of Akpo community indicating (See white dotted lines) several branches (See blue dotted lines). This revealed that the gully morphology is dendritic, spread with a network of branches as indicated in figure 3 . Table 1 and figure 4 also indicated the gully erosion site characteristics and the Gully Site profile respectively. The gully channel is characterised by a V- shape (See plate 1) which is an indication that the surface soils are more erodible than the subsurface soils due to surface run-off producing concentrated overland flows that cut channels [39]. Figure 4 showed the cross section of the gully profile which is the intersection in a certain point along the gully longitudinal axis $(\mathrm{X})$ of the resulting digital elevation model (DEM) with a plane perpendicular to the $\mathrm{X}$-axis results in the cross section.

Results from this study showed that the gully length was $563 \mathrm{~m}$, the maximum elevation was $226 \mathrm{~m}$ and the elevation gain was $0.9 \mathrm{~m}$ representing the length of the horizontal projection of the straight line linking the upper end of both sides and the distances from the deepest points to the gully bed (A1-A2) as confirmed by Well et al. 2010 [40]. The maximum slope was $2.2 \%$ which happens to be responsible for the distribution of the gullies on the spots along farmlands aiding the generation of sufficient volume of run-off. Observations from the field also revealed that the $\mathrm{V}$-shaped channels have high sand content as verified by Egboka, et al. 2016 [41], due to their low cohesion they are unable to support the high vertical sidewalls, and hence, there they can easily collapse.

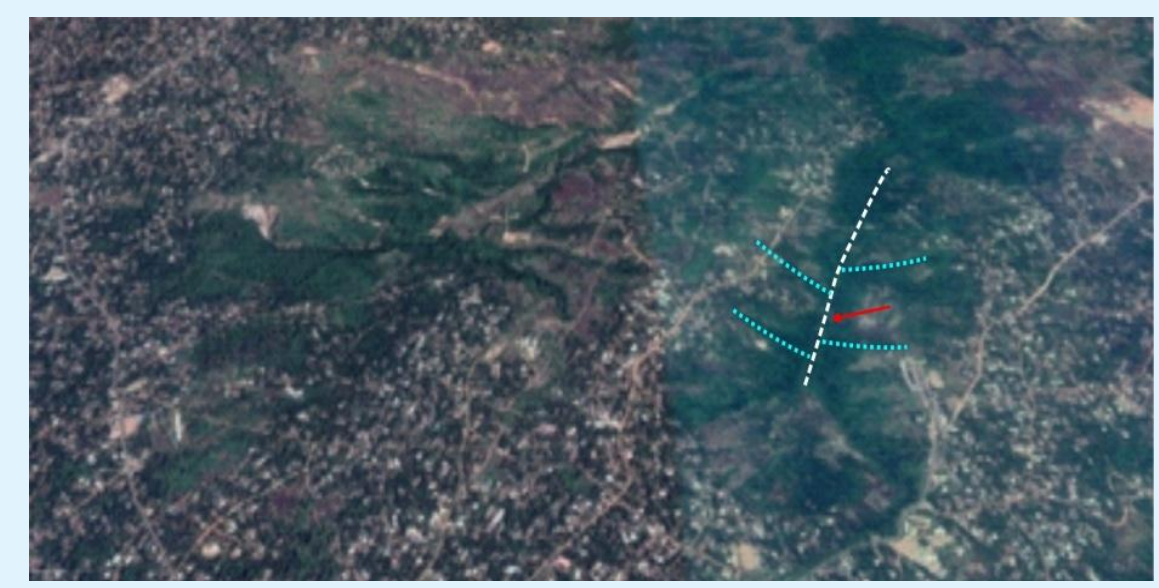

Figure 3: Satellite image of the study area.

Source: Geo-eye Satellite Image (2018) https://support.google.com/earth. 


\section{Journal of Ecology \& Natural Resources}

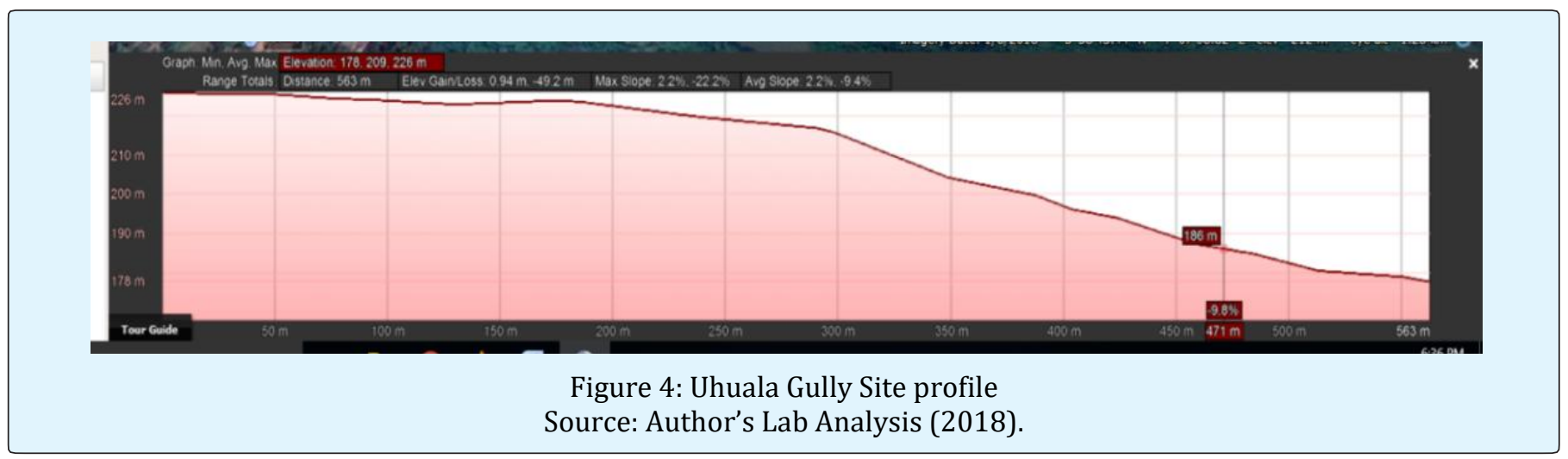

\begin{tabular}{|c|c|c|c|c|c|c|c|}
\hline Classes & $\begin{array}{c}\text { Gully } \\
\text { Length }\end{array}$ & $\begin{array}{c}\text { Average } \\
\text { Elevation }\end{array}$ & $\begin{array}{c}\text { Maximum } \\
\text { Elevation }\end{array}$ & $\begin{array}{c}\text { Minimum } \\
\text { Elevation }\end{array}$ & Elevation Gain & $\begin{array}{c}\text { Elevation } \\
\text { Loss }\end{array}$ & $\begin{array}{c}\text { Minimum/Maximum } \\
\text { slope }\end{array}$ \\
\hline 1 & $563 \mathrm{~m}$ & $209 \mathrm{~m}$ & $226 \mathrm{~m}$ & $178 \mathrm{~m}$ & $0.94 \mathrm{~m}$ & $-49.2 \mathrm{~m}$ & $2.2 \%$ to $-22.2 \%$ \\
\hline
\end{tabular}

Table 1: Characterization of Uhuala Gully Erosion Site.

Source: Result of Author's Lab Analysis, 2018.

Owing to the 8 month duration of rains, with intense concentration on the loose- sands Egboka, et al. 2016 the rains provides forceful volume of run-off that generates gullies along farm routes and lands [41]. Notably, the gullies are extensive covering $563 \mathrm{~m}$ length and $226 \mathrm{~m}$ elevation. This is an indication on the severity of gully erosion in the study area towards a change in landscape, fragmented farmlands and affected agricultural production.

\section{Effect of Gully Erosion on Agricultural Production and Rural Livelihood}

Table 2 showed the response of farmers towards the factors responsible for gully erosion in the study area; $63.2 \%$ of the farmers opined that rainfall is responsible for gully erosion, $3.16 \%$ farmers indicated erodibilty, $6.32 \%$ of the farmers choose agricultural activities, $16.8 \%$ and $10.0 \%$ respondents asserted it was deforestation and nature of the soils respectively. The table is presented in a bar chart (Figure 5).

\begin{tabular}{|c|c|c|}
\hline $\begin{array}{c}\text { Factors of gully erosion to } \\
\text { farmers }\end{array}$ & Frequency & $\begin{array}{c}\text { Percentage } \\
\text { (\%) }\end{array}$ \\
\hline Rainfall & 60 & 63.2 \\
\hline Erodibility & 3 & 3.16 \\
\hline Agricultural activities & 6 & 6.32 \\
\hline Deforestation & 16 & 16.8 \\
\hline Nature of soil & 10 & 10.5 \\
\hline Total & 95 & 100 \\
\hline
\end{tabular}

Table 2: Factors of gully erosion to Akpo community farmers.

Source: Researcher's field work, 2018.

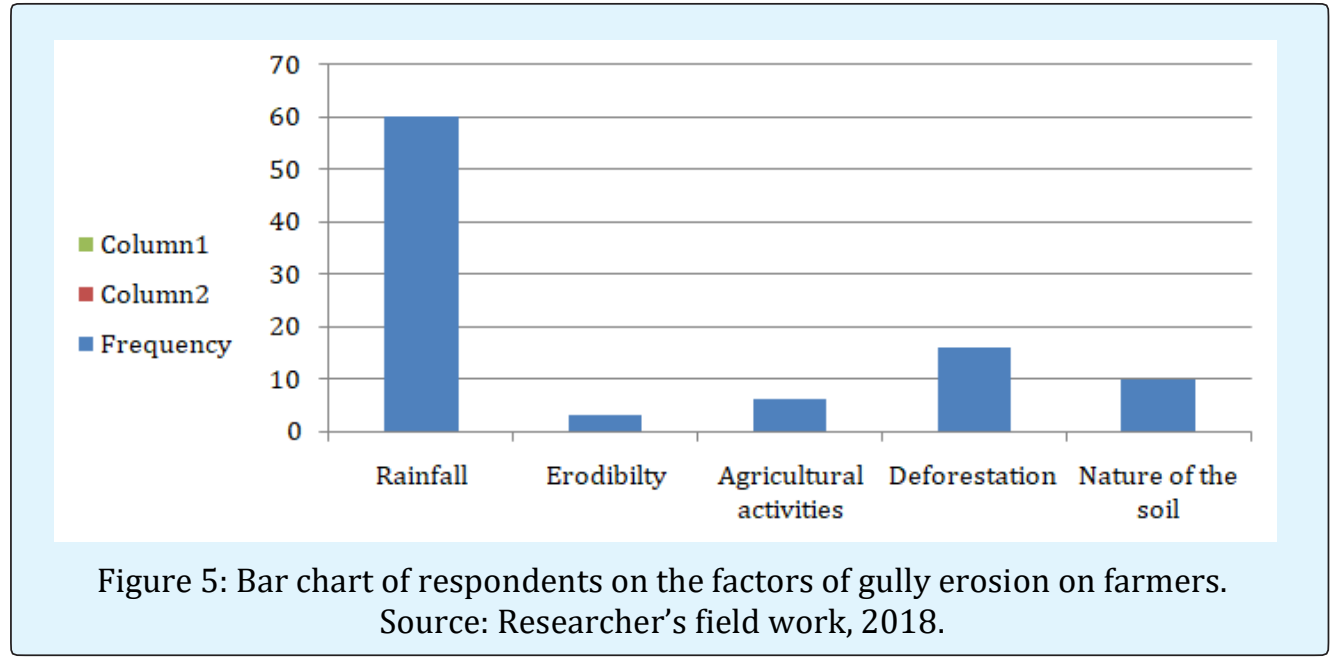

Angela A and Ezeomedo IC. Changing Climate and the Effect of Gully Erosion on Akpo Community Farmers in Anambra State, Nigeria. J Ecol \& Nat Resour 2018, 2(6): 000147. 
Table 3 indicated the frequency distribution of farmers on the influence of gully erosion on crop production. $40.0 \%$ of the farmers strongly agreed, $21.1 \%$ agreed, $20.0 \%$ strongly disagreed while $14.7 \%$ and $4.21 \%$ were scored disagreed and undecided respectively. This implies that $58 \%$ of the farmers agreed that gully erosion affects crop production.

\begin{tabular}{|c|c|c|}
\hline Likert scale & Number of respondents & Percentage (\%) \\
\hline 5= Strongly agreed & 38 & 40.0 \\
\hline 4= Agreed & 20 & 21.1 \\
\hline 3= Undecided & 4 & 4.21 \\
\hline 2= Disagreed & 14 & 14.7 \\
\hline 1=Strongly disagreed & 19 & 20.0 \\
\hline & 95 & 100 \\
\hline
\end{tabular}

Table 3: The Effect of Gully Erosion on Crop Production. Source: Researcher's field work, 2018.

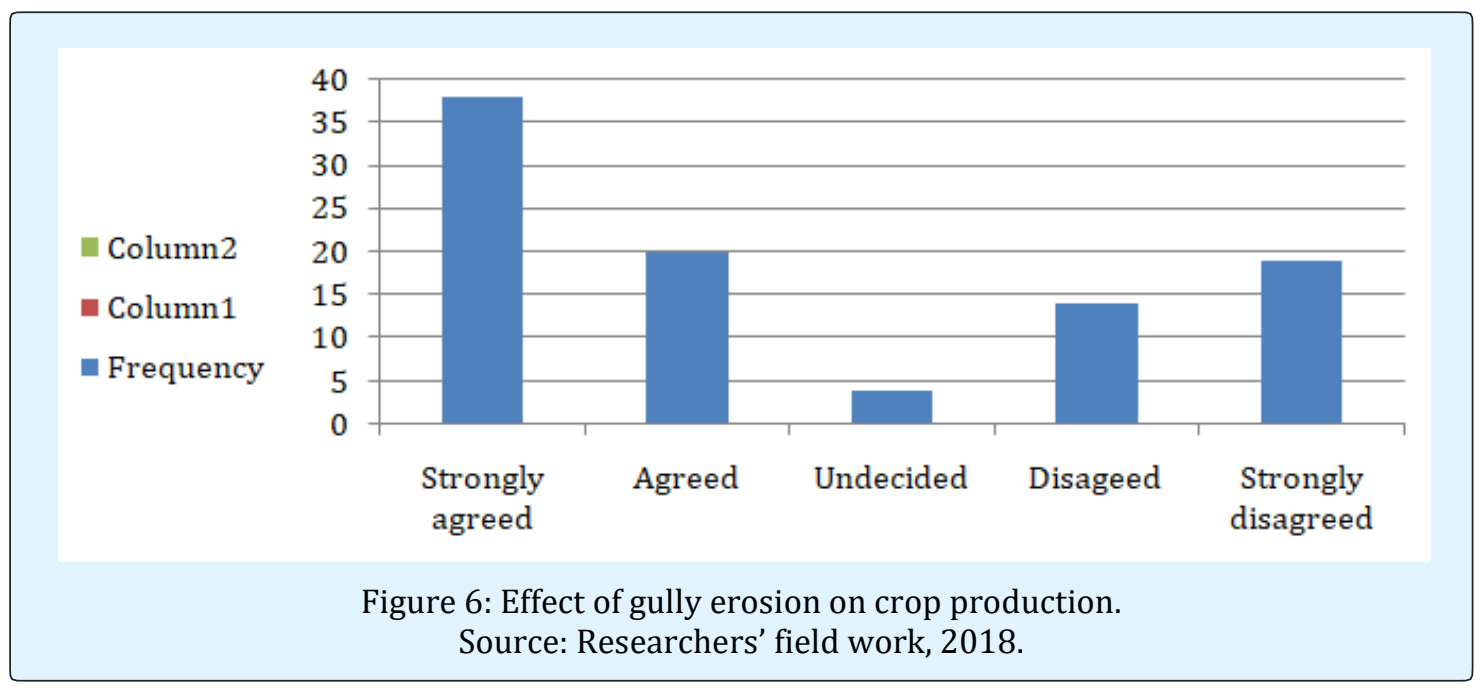

Findings from the study also revealed that residents in the community were mostly adults, married with children and depend on agriculture for their livelihood. Also, a large proportion of the farmers were permanent residents in Uruala village. A large proportion of (94\%) these people had below tertiary education and the land could be their only means of earning income and meeting basic needs. Several studies have related types of jobs and educational level. Agriculture happens to be the source of livelihood to rural farmers who are poor and low income earners as seen in this study.

Most Akpo people have "mbubo" (home garden) and "ubi"(out-station farms) and "ikpa" were they usually cultivate their farm product like cassava, maize, yam, melon, oil and rafia palm in commercial quantities. The location of Akpo within the tropical rainforest gives it ecological basis for production of a wide range of tropical agriculture crop. From findings, it is unfortunate that changed rainfall intensity has increased gully erosion which has negatively affected farming activities.

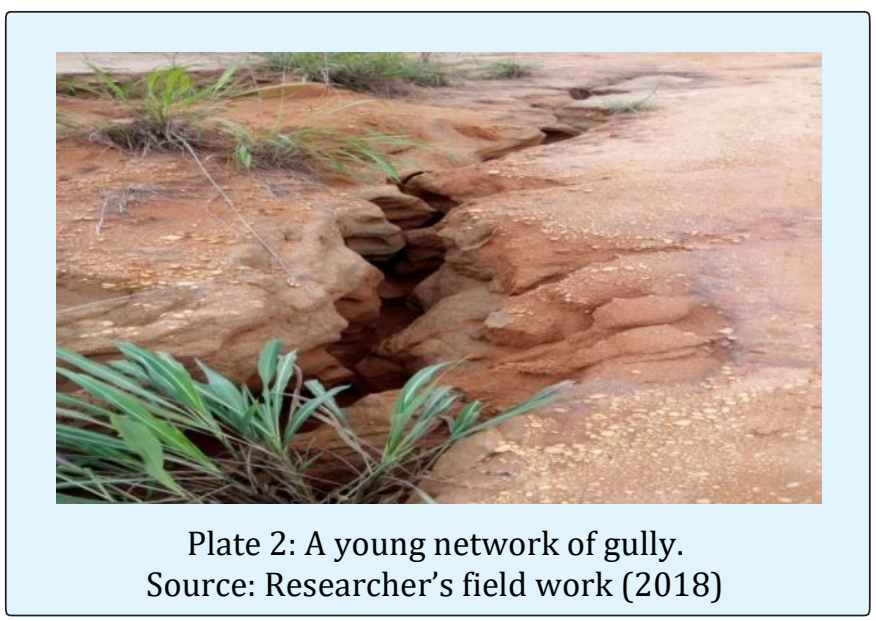




\section{Journal of Ecology \& Natural Resources}
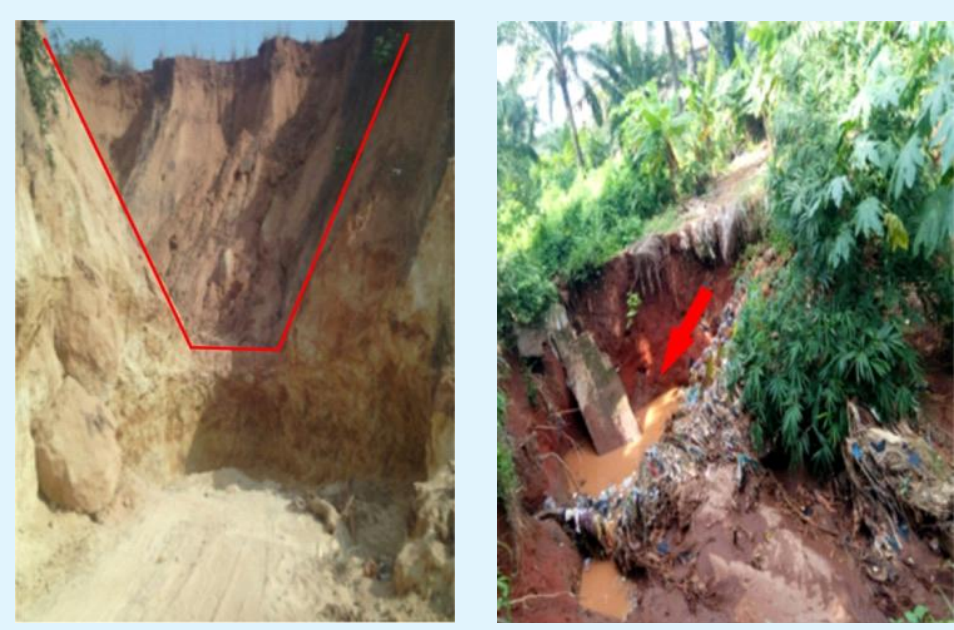

Plate 1: Showing V- shaped gully emanating along farming routes and Banana farms in the study area. Source: Researcher's field work (2018).

The implication of this is that croplands are being fragmented and lost as a result of the gully activities. Similar study carried out by Abdufatai, et al. confirmed the findings in this present work that vast areas of farmlands have been lost to gully erosion while others are at their various stages of destruction leading to drastic decrease in agricultural productivity and ultimately food shortage that can lead to famine if quick-sustainable actions are not applied [28].

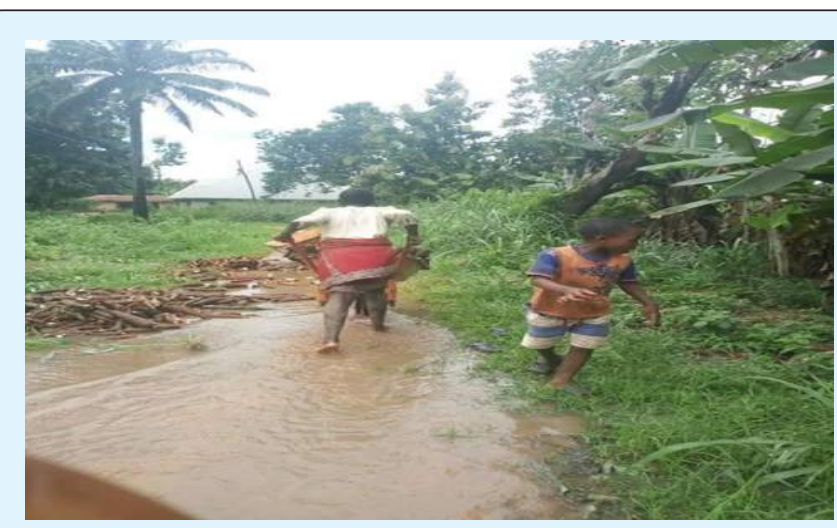

Plate 2: Showing low crop yield of Cassava harvest in the study area.

Source: Researcher's field work (2018)

\section{Socio-economic effect of gully erosion on the residents and farmers at Akpo community}

In addition, the frequency distribution of the respondents regarding the sizes of farmlands in the study area was obtained. $1.05 \%$ had half a standard of land, $36.8 \%$ had $1-5$ plots, $60.0 \%$ had $6-10$ plots and $2.11 \%$ had above 10 plots. Obviously, majority of the lands were employed for farming purposes. Table 4 showed the response of farmers towards the socio-economic effect of gully erosion on Akpo community farmers. $15.8 \%$ and $18.9 \%$ of the farmers opined that development of Bad Lands and poor growth/ harvest of crops had negative effect on farming, $31.6 \%$ and $7.4 \%$ farmers were of the opinion that shortage of land for other uses and loss of biodiversity had negative effect too, while $26.3 \%$ of the respondents stated reduction of farmers income. The table is presented in a bar chart (Figure 7).

\begin{tabular}{|c|c|c|}
\hline $\begin{array}{c}\text { Effect of gully on Akpo } \\
\text { community farmers }\end{array}$ & Frequency & $\begin{array}{c}\text { Percentage } \\
\text { (\%) }\end{array}$ \\
\hline Development of badlands & 15 & 15.8 \\
\hline Poor growth/ harvest of crops & 18 & 18.9 \\
\hline Shortage of land for other uses & 30 & 31.6 \\
\hline Loss of biodiversity & 7 & 7.4 \\
\hline Reduction of farmers income & 25 & 26.3 \\
\hline Total & 95 & 100 \\
\hline
\end{tabular}

Table 4: Socio-economic impact of gully erosion on Akpo community farmers.

Source: Researcher's field work, 2018. 


\section{Journal of Ecology \& Natural Resources}

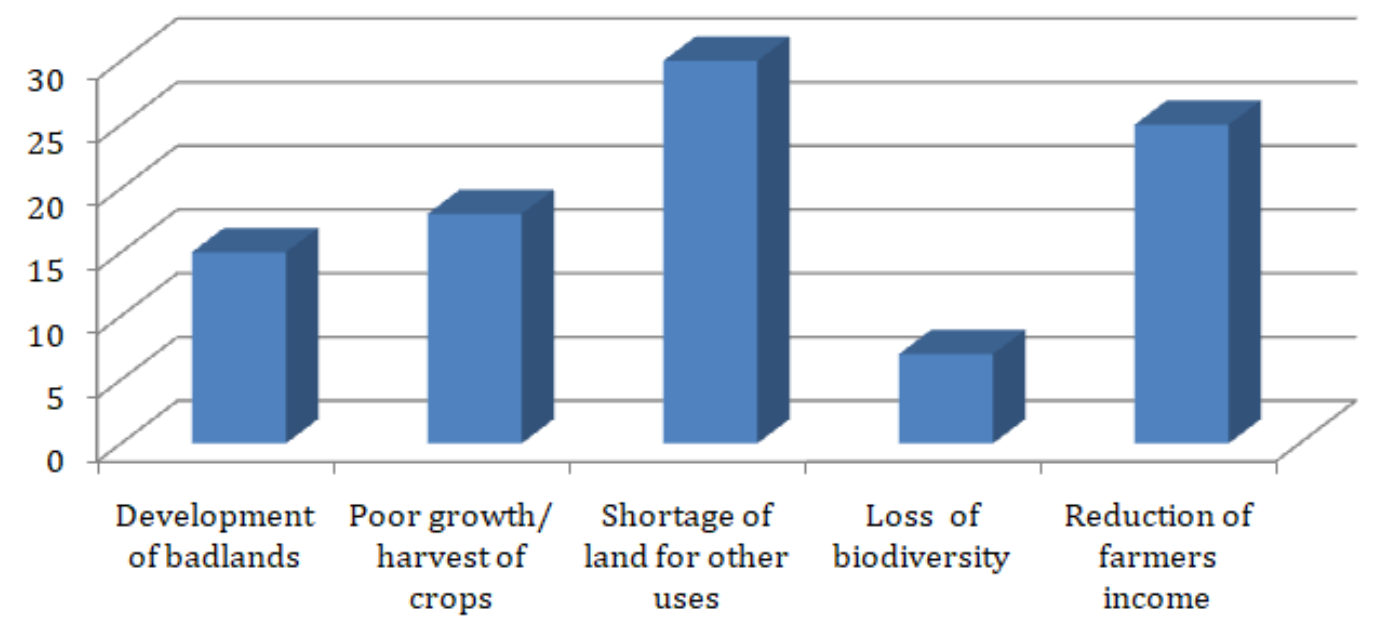

Figure 7: Bar chart of respondents on the impact of gully erosion on Akpo community farmers. Source: Researcher's field work, 2018.

Analysis of chi-square $\left(\mathrm{x}^{2}\right)$

The hypothesis was tested using the inferential statistic of chi-square $\left(\mathrm{x}^{2}\right)$. This was aimed at testing the opinions of the effect of gully erosion on Akpo community farmers in Table 4.
$\mathrm{H}_{0}$ : There is no significant effect of gully erosion on Akpo community farmers.

\begin{tabular}{|c|c|c|c|c|c|}
\hline $\begin{array}{c}\text { Effect of gully erosion } \\
\text { on farmers }\end{array}$ & $\begin{array}{c}\text { Development of } \\
\text { bad land }\end{array}$ & $\begin{array}{c}\text { Poor growth/harvest } \\
\text { of crops }\end{array}$ & $\begin{array}{c}\text { Shortage of land for } \\
\text { other uses }\end{array}$ & $\begin{array}{c}\text { Loss of } \\
\text { biodiversity }\end{array}$ & $\begin{array}{c}\text { Reduction of } \\
\text { farmers' income }\end{array}$ \\
\hline Number of respondents & 15 & 18 & 30 & 7 & 25 \\
\hline
\end{tabular}

Table 5: Effect of gully erosion on Akpo community farmers. Source: Researcher's field work, 2018.

$\mathrm{X}_{5}=82.2, \mathrm{P}<0.01$

The study observed that there is a significant impact of gully erosion on socio-economic status of Akpo community farmers $\left(\mathrm{x}^{2}{ }_{5}=82.2, \mathrm{P}<0.01\right)$. The calculated value of $x^{2}=82.2$ exceed the critical value (tabulated value) of 15.09 at $\mathrm{P}<0.01$. Thus, the null hypothesis is rejected in favour of alternative hypothesis.

\begin{tabular}{|c|c|c|}
\hline Yes & No & Total \\
\hline 65 & 30 & 95 \\
\hline
\end{tabular}

Table 6: Effect of gully erosion on Akpo community farmers.

Source: Researcher's field work, 2018.

$\mathrm{X}^{2}{ }_{1}=13.1, \mathrm{P}<0.01$

The study observed that there is a significant difference on the effect of gully erosion on socio-economic status of Akpo community farmers $\left(\mathrm{x}^{2}{ }_{1}=13.1, \mathrm{P}<0.01\right)$. The calculated value of $x^{2}=13.1$ exceed the critical value (tabulated value) of 6.63 at $\mathrm{P}<0.01$. Thus, the null hypothesis is rejected in favour of alternative hypothesis [42].

From the respondents' perception, gully erosion impacted significantly on various aspects of farming performance in Akpo as indicated in Table 4. Farmers revealed that gully erosion has the most significant impact on these performance variables through the deleterious effect it had on farmlands, poor growth/harvest of crops (especially economic trees like Avocado, Pear, Kola nut, Breadfruit and Berry), development of a bad land, shortage of land for other uses, loss of biodiversity and reduction of farmers' income. It was noted that majority of the farmers use animal manure for crop production because of the loss of soil fertility 


\section{Journal of Ecology \& Natural Resources}

which is as a of gully erosion. However, it is recommended that farming dispositions that escalate climate change problems should be regulated such as deforestation, bush burning and continuous/monocropping farming among others. Adaptive measures should be applied by farmers against gully erosion such as use of agroforestry and afforestation for carbon capture, climate change - awareness and education, the use of resilient crops/seeds and improved farm technology, meteorological awareness and weather prediction.

\section{Conclusion}

The study investigated the changing climate and the effects of gully erosion on Akpo community farmers in Anambra State, Nigeria. Findings from the study showed that $94 \%$ of the respondents were below tertiary education and the land is their major means of livelihood. It was also noted that majority of the farmers (63.2\%) agreed that rainfall is responsible for the large extent of gully erosion while $40 \%$ indicated that gully erosion affected their crop production.

Findings from the study also showed that gully erosion in Akpo community is dendritic and has a network of branches. Gully erosion characterization indicated a Vshape. This showed that surface soils are more erodible than the subsurface soils due to surface run-off producing concentrated overland flows that cut channels. Further, the length of the gully was $563 \mathrm{~m}$, the maximum elevation was $226 \mathrm{~m}$ and the elevation gain was $0.9 \mathrm{~m}$ representing the length of the horizontal projection of the straight line linking the upper end of both sides and the distances from the deepest points to the gully bed. The maximum slope was $2.2 \%$ which happens to be responsible for the distribution of the gullies on the spots along farmlands aiding the generation of sufficient volume of run-off.

Farmers revealed that gully erosion has the most significant effect on their farmlands, poor growth/harvest of crops (especially economic trees like Avocado, Pear, Kola nut, Breadfruit and Berry), and development of fragmented lands, shortage of land for other uses, loss of biodiversity and reduction of farmers' income. The farmers could relate to the fact that there has been a rapid change in rainfall intensity, which has increased the spread of gully erosion, changed the growing seasons, affected the performance of their harvest and most of all food security and livelihoods were threatened.

As the Director of National Emergency Management Agency (NEMA), Walson Ibarakumo in Today's Nigeria Newspaper (July 2018) confirmed that:
"The heavy rainfall, storms and winds currently experienced in the State is as s result of climate change. Climate change has brought about a lot of changes in our environment amongst which is the flood risk that has been forecasted by the News Agency of Nigeria.

\section{References}

1. United Nation Environmental Protection Agency (US EPA, 2017) Climate Change. Pacific Southwest, Region 9. Information on regional clean energy and climate change resources.

2. US National Oceanic and Atmospheric Agency and NASA (NOAA \& NASA) Scientists on climate change trend. 2018 continues Earth's recent warming trends by Mark Kaufman 2018-07-18 14: 19:31 UTC.

3. IPCC (2014) The Fifth Assessment Report of United Nations Intergovernmental Panel on Climate Change, Threat from Global Warming. Reuters, Environment.

4. Nigerian Meteorological Agency (NIMET) (2018) Seasonal Rainfall Predictions (2018) A Report by NIMET, pp: 47.

5. Poesen J, Vandekerchove L, Nachergaele DD, Wisdenes G, Verstraeten G (2002) Gully Erosion in Dry Land environment. In: Dry Land Rivers. Hydrology and Geomorphology of Semi-arid Channels, pp: 229-262.

6. Pathak P, Wani SP, Sudi R (2005) Gully Control in SAT Watersheds. Global Theme on Agroecosystems. International Crops Research Institute for the SemiArid Tropics, pp: 28.

7. Fournier FT (2000) Land Use Soil Conversion in Parts of Onitsha and Owerri Province. Geological Survey of Nigeria. Bulletin No: 21.

8. Morgan RDC (2000) Soil Erosion, In: Donald D, Davidson J (Eds.). Topics in Applied Geomorphology London, Longman Group Ltd, pp: 91-99.

9. Schmittner KE, Giresse P (1999) The Impact of Atmospheric Sodium on Erodibility of Clay in Coastal Mediterranean Region. Environ Geol 37(3): 195-206.

10. Stocking MA (2005) Causes and Prediction of the Advancement of Gullies. In: Tangsanchalli and Egger (Eds.), Problems of Soil Erosion and Sedimentation. SouthEast Asian Regional Symposium. Asian Institute of Technology, Bangkok, Thailand. 
11. Chukwunonso GI (2014) Impact of Climate Change on Agricultural Production and Sustainability in Nigeria. Asian J Agricul Extension Economics Sociol 4(1): 29 41.

12. Rui L, Shu G (2013) Impacts of Climate Change on Agriculture and Adaptive Strategies in China. J Integrative Agri 12(8): 1402-1408.

13. Zapp DH, Nearing MA (2005) Slope Shape Effects on Erosion: a Laboratory Study. Soil Sci Soc Am J 69: 1463-1471.

14. Bennett SJ, Casali J, Robinson KM, Kudary KC (2000) Characteristics of Actively Eroded Ephemeral Gullies is on Experimental Channel Internal Symposium on Gully Erosion under Change. Cath University of Leuven, Belgium, pp: 16-19.

15. Weggei RJ, Rustom R (2002) Soil Erosion by rainfall and runoff-State of the Art. Geotextiles Geomembrances 11(4-6): 551-572.

16. Anne Schmitt, Markus Dotterweich, Gabriele Schmidtchen, Hans-Rudolf Bork (2003) Vineyards, hopgardens and recent afforestation, effects of late holocene land use change on soil erosion in northern bavaria, Germany. Catena 51(3-4): 241-254.

17. Daba S (2003) An Investigation of the Physical and Socioeconomic Determinants of Soil Erosion in the Hararghe Highlands, Eastern Ethiopia. Land Degradation and Development 14(1): 69-81.

18. Abraham CM (2010) Implications of Gully Development on Agricultural Production in Akwa Ibom State. Unpublished Ph.D. Thesis submitted to the University of Uyo, Akwa Ibom State, Nigeria.

19. Zegeye AD, Abiy Az, Tebebu TY, Easton ZM, Tilahun SA, et al. (2010) Surface and Subsurface Flow Effect on Permanent Gully Formation and Upland Erosion near Lake Tana in the Northern Highlands of Ethiopia. Hydrol Earth Sys Sci 14(11): 2207-2217.

20. United States Global Change Research Information Office (2001).

21. Ezeigwe PC (2015) Evaluation of Socio-Economic Impacts of Gully Erosion in Nkpor and Obosi. Environ Res 7(7): 34-38.

22. Kalu AC (2001) Soil Erosion and Landslides: $21^{\text {st }}$ Century Issues and Challenges to Rural Development in Nigeria. Unpublished MURP Seminar Paper: Department of Urban and Regional Planning, Abia State University, Uturu Abia State, Nigeria.

23. Igbokwe JI (2008) Gully Erosion Mapping/Monitoring in Parts of South Eastern Nigeria. Paper Presented at Department of Surveying and Geoinformatics, Nnamdi Azikiwe University, Awka, Anambra State.

24. Shit PK, Maiti R (2002) Rill Gully Erosion. In: Bad Land Topography: Field Measurement and Monitoring (A Case Study on the Western Part of West Bengal, India). LAP LAMBERT Academic Publishing, Germany, pp: 136.

25. Umah KA, Justin U, Braimoh J (2016) Investigating the Impacts/Causes of Gully Erosion in Auchi, Nigeria. J Geography Environ Earth Sci 4(4): 1-13.

26. Ofomata GEK (2000) Missing Links in the management of Soil Erosion Problems in Nigeria. In: Environmental Pollution and Management in the Tropics, Snap Publishers.

27. Poesen J (2011) Challenges in Gully Erosion Research. Landform Analysis 17: 5-9.

28. Abdulfatai IA, Okinlola IA, Akande WG, Momoh LD, Ibrahim KO (2014) Review of Gully Erosion in Nigeria: Causes, Impacts and Possible Solutions. J Geosci Geomatics 2(3): 125-129.

29. World Commission for Environment and Development (WCED) (1987) Our Common Future. Oxford University Press.

30. Akanwa AO (2016) Effects of Quarrying Activities on Local Vegetation Cover in Ebonyi State. A PhD Dissertation presented at Centre for Environmental Management and Control (CEMAC), University of Nigeria Nsukka, Nigeria.

31. National Emergency Management Agency (NEMA, 2018) Rainfall Pattern, Flooding, Storms an interview with the Director of (NEMA) Walson Ibarakumo on Climate change.

32. Yu B, Neil DT (2008) Long-Term Variations in Regional Rainfall in the South-West of Western Australia and the Difference between Average and High Intensity Rainfalls. Int J Climatol 13(1): 77-88.

33. Othieno RT, Laycock EP (2007) Monitoring Soil Organic Carbon Erosion with Isotopic Tracers, Two 
Case Studies on Cultivated Tropical Catchments with Steep Slopes Laos, Venezuela. Advances in Soil Science. CRC Press, Boca Raton, Florida, USA.

34. Ayinde OE, Muchie M, Olatunji GBC (2011) Effects of Climate Change on Agricultural productivity in Nigeria: A Co-integration Model Approach. J Human Eco 35(3): 189-194.

35. Inyang IT (2000) Climate Zonation of the Rain Forest Zone of Eastern Nigeria. Geological Society of Nigeria Annual Report 5127.

36. Ezechi JF (2000) The Influence of Runoff, Lithology and Water Table on the Dimensions and Rates of Gullying Processes in Eastern Nigeria. International Symposium on Gully Erosion under Global Change. Cath University of Lerner, Belgium, pp: 28-29.

37. Umudu M (2008) Residence Flee as Erosion Eats up Anambra Community. Vintage Press Ltd, Lagos.

38. Parker C, Thorne C, Binger R, Wells R, Wilcox D (2007) Automated Mapping of Potential for

\section{Journal of Ecology \& Natural Resources}

Ephemoral Gully Formation in Agriculture Watersheds. Laboratory Recreation National Sedimentation Laboratory NO56.

39. Kirkby MS, Bracken LJ (2009) Gully Processes and Gully Dynamics. Earth Surface Processes Landforms 34(14): 1841-1851.

40. Wells R, Benneh S, Alonso C (2010) The Effect of Upstream sediments inflow on the Morphodynamics of Head cut $2^{\text {nd }}$ Joint Federal Interagency Conference, Las Vegas, Nevada, USA.

41. Egboka BC, Okoyeh EI (2016) The Impact and Implication of Anthropogenic Forces on the Unstable geologic Platform in Parts of Anambra and Imo States, Southern Nigeria. Int J Environ Prot Policy 4(4): 104110.

42. Peter CN (2011) An Assessment and Mapping of Gully Erosion Hazards in Abia State: A GIS Approach. J Sustain Develop 4(5): 8-11. 